\title{
BENDING STRENGTH AND STIFFNESS OF POLES OF ARGENTINEAN Eucalyptus grandis
}

Torrán E.A², Sosa Zitto M.A. ${ }^{2}$, Cotrina A.D. ${ }^{2}$, Piter J.C. ${ }^{1}$

\begin{abstract}
The present paper reports the results of an investigation regarding the determination of bending strength and stiffness in full-size poles of Argentinean Eucalyptus grandis. The importance of accurately knowing the mechanical properties of this material has increased with the increasing demand of utility poles of this species and with the use of modern procedures aimed at achieving a reliable and economical structural design. For this purpose an empirical research project with two samples containing new, green, untreated poles was carried out according to the procedures adopted by both the American standard ASTM D 1036 (2005) and the Argentinean standard IRAM 9529 (2004) for cantilever bending tests. Sample 1 enclosed 14 year-old poles with nominal length of $12 \mathrm{~m}$ and Sample 2 enclosed 11 year-old poles with nominal length of $8 \mathrm{~m}$. The results found for the average circumference taper were similar to the values adopted by the American standard ANSI 05.1 (2002) and knot dimensions as well as knot ratio compared well with those permitted by this standard. The mean value found for maximum fibre stress at ground line reached $62.9 \mathrm{~N} / \mathrm{mm}^{2}$ for Sample 1 and $56.3 \mathrm{~N} / \mathrm{mm}^{2}$ for Sample 2 . These strength results are relatively high in comparison with values reported for seasoned sawn timber of the same species and they compare well with those published by the American standard ANSI 05.1c (2004) for poles of different species. Both samples showed a coefficient of variation of $13 \%$ for strength at ground line which is relatively low in comparison with those adopted by the American standard and may be considered an advantage of this material for structural purposes. The mean value found for modulus of elasticity reached $10935 \mathrm{~N} / \mathrm{mm}^{2}$ for Sample 1 and $9546 \mathrm{~N} / \mathrm{mm}^{2}$ for Sample 2, with a coefficient of variation of $14 \%$ for both cases. Results also revealed significant differences between mechanical properties values corresponding to the two samples containing poles with different sizes and age. The correlation coefficient between knot ratio and strength showed the insignificant values of 0.09 and 0.02 for Sample 1 and 2 respectively, and the corresponding results between modulus of elasticity and strength were 0.52 and 0.37 .
\end{abstract}

Keywords: poles, Eucalyptus grandis, strength and stiffness

\section{RESUMEN}

En el presente trabajo se presentan los resultados de una investigación orientada a determinar la resistencia y la rigidez de postes de Eucalyptus grandis de Argentina. La importancia de conocer con precisión las propiedades mecánicas de este material cobró mayor relevancia con la creciente demanda de postes de esta especie y con la adopción de modernos procedimientos de cálculo orientados a lograr un diseño estructural confiable y económico. Con este fin se llevó a cabo un proyecto empírico que abarcó dos muestras de postes en tamaño estructural, nuevos y sin tratamientos, los cuales se ensayaron en estado verde conforme a los procedimientos establecidos en la norma estadounidense ASTM D 1036 (2005) y en la Argentina IRAM 9529 (2004) para pruebas en voladizo. La muestra 1 incluyó postes

\footnotetext{
${ }^{1}$ Director del Grupo de Estudio de Maderas (GEMA), Depto. Ing. Civil, Facultad Regional C. del Uruguay, Universidad Tecnológica Nacional. Calle Ing. Pereira 676, (E3264BTD) Concepción del Uruguay, Entre Ríos, Argentina.

${ }^{2}$ Investigadores del Grupo de Estudio de Maderas (GEMA).

Corresponding author: piterj@frcu.utn.edu.ar

Received: 27.05.2008. Accepted: 19.01.2009
} 
con $12 \mathrm{~m}$ de longitud nominal y una edad de 14 años, y la muestra 2 estuvo compuesta por postes con $8 \mathrm{~m}$ de longitud nominal y una edad de 11 años. Los valores promedio encontrados para la conicidad fueron similares a los adoptados por la norma ANSI 05.1 (2002) y tanto el tamaño de los nudos como la nudosidad compararon bien con los valores permitidos por esta norma. El valor medio de la tensión de rotura en la línea de empotramiento fue de $62,9 \mathrm{~N} / \mathrm{mm}^{2}$ para la Muestra 1 y de $56,3 \mathrm{~N} / \mathrm{mm}^{2}$ para la Muestra 2. Estos resultados son relativamente altos en comparación con los publicados para madera aserrada de la misma especie ensayada en estado seco y son comparables a los adoptados por la norma ANSI 05.1c (2004) para postes de diferentes especies. Ambas muestras exhibieron un coeficiente de variación de $13 \%$ para la resistencia en la línea de empotramiento, valor que es relativamente bajo en comparación con los adoptados por la norma estadounidense y puede ser considerado una ventaja del material para uso estructural. El valor medio del módulo de elasticidad alcanzó $10935 \mathrm{~N} / \mathrm{mm}^{2}$ para la muestra 1 y $9546 \mathrm{~N} / \mathrm{mm}^{2}$ para la muestra 2, con un coeficiente de variación de $14 \%$ en ambos casos. Los resultados también pusieron de manifiesto diferencias significativas entre los valores de las propiedades mecánicas de ambas muestras, integradas por postes de diferentes edades y dimensiones. El coeficiente de correlación entre la nudosidad y la resistencia alcanzó los insignificantes valores de 0,09 para la muestra 1 y de 0,02 para la muestra 2 , mientras que los valores correspondientes entre el módulo de elasticidad y la resistencia fueron 0,52 y 0,37 .

Palabras clave: postes, Eucalyptus grandis, resistencia y rigidez.

\section{INTRODUCTION}

Eucalyptus grandis, which is mainly cultivated in the Mesopotamian provinces of Entre Ríos and Corrientes, is one of the most important renewable species cultivated in Argentina. There is an important domestic demand of utility poles for electric and phone structures and this material is sometimes also requested from abroad. For purposes related to single-pole utility structures, these poles are normally separated in two different groups, based on their length. One group encloses the so-called long poles, with a length ranging from $10 \mathrm{~m}$ to $15 \mathrm{~m}$. The other group encloses the standard poles, which are widely used and have a length ranging from $7 \mathrm{~m}$ to $9 \mathrm{~m}$ (INTA 1995). Apart from being a renewable resource, round wood also gives a very good ecological balance, because sawing is not needed and the use of primary energy is minimised (Winter 1995). Consequently, the use of this type of structures is also convenient for taking care of environmental aspects.

The knowledge of bending strength and stiffness of this material is very important for a reliable and economical design. The influence of growth and geometry characteristics on mechanical properties, as well as the consideration of in-service moisture content are also very important for achieving a uniform level of reliability of this type of structures. Traditionally, decisions related to strength values were based on a combination of full-size pole test results and published small clear specimen strength values (Wolfe et al. 2001). In spite of the importance of employing strength values determined on structuralsized poles, these data are not available in some countries and design is based on results obtained on small clear specimen tests (Alves Dias et al. 2004).

Up to the present neither test series regarding the determination of bending strength and stiffness of poles of Argentinean Eucalyptus grandis in structural sizes has been published nor study regarding the influence of the more important strength and stiffness reducing growth characteristics has been reported for this material. As a consequence, the characteristic values of its mechanical properties are not well known and it is not considered a reliable material. Data obtained from tests carried out on sawn timber of Argentinean Eucalyptus grandis in structural sizes are available (Piter et al. 2004a) and they may be used as reference values when studying the pole properties of this species. However, since round wood is only debarked, higher strength values can be expected for it than for sawn timber because the material is left in a natural form and longitudinal fibres are not cut as in sawn timber (Winter 1995). 
With the purpose of studying the possibility of strength grading these poles, reports related to the usefulness of visual as well as machine parameters for predicting the strength of this species were analysed. Results of a project regarding the design of a method for visually strength grading sawn timber of Argentinean Eucalyptus grandis show the influence of the more important strength and stiffness reducing features (Piter et al. 2004a). This paper reports a relatively modest relationship between knot ratio and bending strength in comparison with other timber species. It also informs that in many cases it is impossible to distinguish the annual rings. Very low slope of grain was also found. Modulus of elasticity emerges as the most important grading parameter from a project regarding the design of a method for machine strength grading sawn timber of this species (Piter et al. 2004b). A very good correlation between this property and strength was found, which is only slightly lower than that obtained between a combined parameter (modulus of elasticity with density and knot ratio) and strength.

Specifications providing material quality limitations, standard product sizes and strength and stiffness data are available in the American standards ANSI 05.1 (2002) and ANSI 05.1c (2004). The testing methods adopted by both the American standard ASTM D 1036 (2005) and the Argentinean standard IRAM 9529 (2004) cover testing procedures in sufficient detail so that they allow to obtain comparable results.

The aim of this paper is to present and discuss the results of an investigation regarding the determination of bending strength and stiffness of full-size poles of Argentinean Eucalyptus grandis. Additionally, to compare these results with those published by other researchers and standards and to analyse the relationship between strength and both knot ratio and modulus of elasticity.

\section{MATERIAL AND METHODS}

Two test samples containing new, green, untreated poles were utilised. One sample, taken from the sub-population of the so-called long poles, enclosed 57 specimens with nominal length of $12 \mathrm{~m}$ which were randomly selected from a 14 year-old plantation of Eucalyptus grandis (hereafter Sample 1). The other sample, taken from the sub-population of the standard poles, enclosed 48 poles with nominal length of $8 \mathrm{~m}$ which were randomly selected from an 11 year-old plantation of the same species (Sample 2). Both plantations were cultivated in Concordia, Entre Ríos, which is one of the main provenance for this species in Argentina (INTA 1995). After harvesting and peeling, the material was transported to the test site in order to test all specimens in green condition.

Actual length and circumference at butt, at tip, at ground line, at loading point and at every $0.50 \mathrm{~m}$ from the butt were measured and recorded for each pole. Growth rings were measured at butt and all prohibited or limited defects by the American standard ANSI 05.1 (2002) were registered. In accordance with the criterion adopted by this standard, the dimension of a knot was considered equal to its diameter on the surface of the pole measured in a direction at right angles to the lengthwise axis of the pole. Dimension and location of all knots were taken and recorded. The following knot sizes were particularly registered for each pole: i) the largest single knot $(\mathrm{K})$ located in both the lower and the upper half of pole length, and ii) the largest sum of knots in any $0.31 \mathrm{~m}$ of the length of the pole (SuK). Knot ratio was expressed for each pole according to the following criterion: relation of the greatest sum of knot in any $0.31 \mathrm{~m}$ of the length of the pole and the average circumference of the same $0.31 \mathrm{~m}$ section (SuKR). No distinctions were made between different types of knots, and those with diameters less than $13 \mathrm{~mm}$ were ignored. Spiral grain was determined by means of a swivel-handled scribe and expressed as a ratio, disregarding local deviations.

After physical measurements and features were taken and recorded, cantilever bending tests were carried out according to the procedures of the American standard ASTM D 1036 (2005) which were also adopted by the Argentinean standard IRAM 9529 (2004). Each pole was placed in the testing appa- 
ratus so that its ground line coincided with the front face of the crib and then it was rotated to find the best position for minimizing the out-of-plane stresses as prescribed. The ground line distance from butt was equal to $1.8 \mathrm{~m}$ for the poles of Sample 1 and to $1.4 \mathrm{~m}$ for those of Sample 2. The loading point was located at $0.6 \mathrm{~m}$ from the tip in all cases. Before loading, the actual distance from the ground line to the loading point was taken and recorded for each pole. A rail was provided at a point about three quarters of the distance from the ground line to the point of load application to minimize vertical movement at that point and reduce the stress from the weight of the pole. This support was installed in such a way that any friction associated with the deflection of the pole under load was not a significant portion of the measured load on the pole. A schematic diagram of test setup may be appreciated in Figure 1.

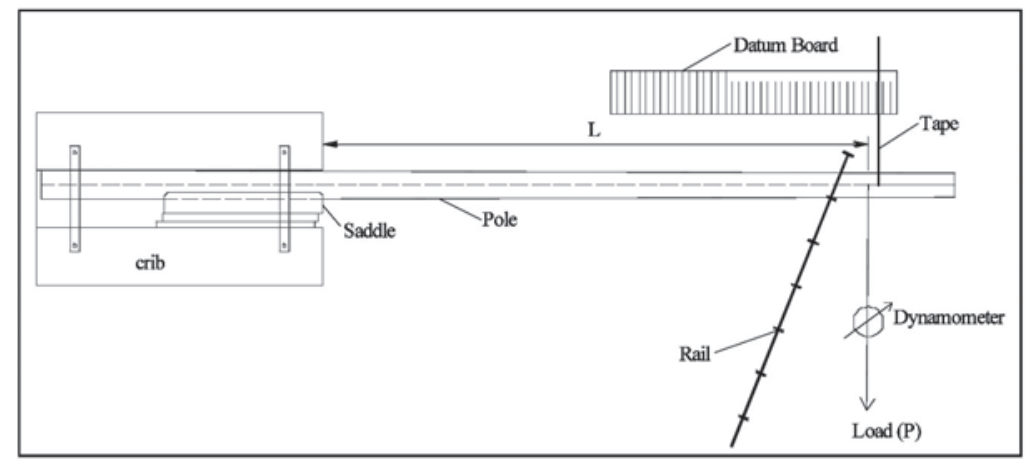

Figure 1. Test arrangement

Load was applied by means of a winch capable of pulling at a constant rate of speed. According to the criterion of the American standard mentioned before, test speed reached $350 \mathrm{~mm} / \mathrm{min}$ for poles of Sample 1 and $150 \mathrm{~mm} / \mathrm{min}$ for those of Sample 2. The winch was set far enough from the pole so that the small angle between the initial and the final position of the pulling line may be disregarded. Load was measured by means of a dynamometer of suitable capacity $(50 \mathrm{kN})$ placed in series in the pulling line and graduated in $0.1 \mathrm{kN}$. Deflections at loading point in the direction perpendicular to the initial pole axis were measured by means of a tape capable of registering $1 \mathrm{~mm}$ and a datum board was also utilised for facilitating the measurements. A minimum of 15 simultaneous readings of deflection and load were taken at intervals of load equal to $0.5 \mathrm{kN}$. The lever arm shortening between the point of load and both the ground line and the point of break was measured and registered for each pile.

The maximum fibre stress was calculated for each pole at ground line $(\mathrm{F})$ and at breaking point $\left(\mathrm{F}_{\mathrm{b}}\right)$ by using the formulae established in the American standard ASTM D 1036 (2005) as follows:

where:

$$
F=\frac{32 \pi^{2} P\left(L-\Delta_{L}\right)}{C^{3}}
$$

P: load at failure, L: distance from ground line to point of load, $\Delta_{\mathrm{L}}$ : lever arm shortening between ground line and point of load, $\mathrm{C}$ : circumference at ground line.

where:

$$
F_{b}=\frac{32 \pi^{2} P\left(a-\Delta_{a}\right)}{C_{a}{ }^{3}}
$$

P: load at failure, a: distance from break to point of load, $\Delta_{\mathrm{a}}$ : lever arm shortening between the point of break and point of load, $\mathrm{C}_{\mathrm{a}}$ : circumference at point of break. 
The modulus of elasticity (E) was determined with the equation adopted by the American standard mentioned before as follows:

$$
E=\frac{4 L^{3} P}{3 \pi \Delta A^{3} B}
$$

where:

L: length from ground line to loading point, P: increment of load on the straight line portion of the load deformation curve, $\Delta$ : increment of deformation corresponding to $\mathrm{P}$ and corrected for movement at point of support, A: radius of pole at ground line, B: radius of pole at point where load was applied.

Moisture content and density were determined according to the procedures established in ISO 3130 (1975) and ISO 3131 (1975) respectively, using a knot-free disk taken from the proximity of the breaking point after the static test. Minimum (Min), mean and maximum (Max) values as well as the coefficient of variation $(\mathrm{COV})$ were calculated according to the standard procedures and the $5^{\text {th }}$ percentile was obtained by assuming a normal distribution.

\section{RESULTS AND DISCUSSION}

Moisture content ranged between $37 \%$ and $52 \%$ with a mean value of $45 \%$ for Sample 1 whereas it ranged from $38 \%$ to $55 \%$ with a mean value of $47 \%$ for Sample 2 . These results confirm that all poles presented moisture content above fibre-saturation point when they were loaded (Coronel 1994, Hoffmeyer 1995). Density, determined with the values of moisture content mentioned before, showed a mean value of $707 \mathrm{~kg} / \mathrm{m}^{3}$ with a COV of $40 \%$ for Sample 1 . The corresponding values for Sample 2 were $682 \mathrm{~kg} / \mathrm{m}^{3}$ and $41 \%$.

Table 1 exhibits the main results for circumference and length. The average circumference taper per foot of length is an important value for calculating the load-carrying capability of poles according to the American standard ANSI 05.1 (2002). A detailed analysis of the results presented in Table 1 showed an average circumference taper (per $0.31 \mathrm{~m}$ of length) between butt and tip equal to $8 \mathrm{~mm}$ for Sample 1 and $6 \mathrm{~mm}$ for Sample 2 but these values varied within the length of the poles. The values obtained between butt and ground line were $12 \mathrm{~mm}$ and $9 \mathrm{~mm}$ for Sample 1 and Sample 2, respectively, whereas those calculated between ground line and tip reached $7 \mathrm{~mm}$ for Sample 1 and $5 \mathrm{~mm}$ for Sample 2. Apart from the result obtained for the average circumference taper between butt and ground line in Sample $1(12 \mathrm{~mm})$, the values found in this research are similar to those adopted by the American standard, which range between $5 \mathrm{~mm}$ and $10 \mathrm{~mm}$ for different species. This table also shows that circumference exhibited much greater COV values for Sample 1 than for Sample 2. The important difference found for the spread of circumference results corresponding to both samples may be explained by the fact that long poles of this species are not available in great amount and they normally present a high variability in dimensions in comparison with standard poles.

In many cases it was impossible to distinguish the annual rings, and slope of grain exhibited a maximum value of $1 / 9$. Spiral grain showed in all cases lower values than the limits adopted by the American standard ANSI 05.1 (2002) for poles with nominal lengths as the ones corresponding to Sample 1 and Sample 2. These results are congruent with previous reports of other investigations carried out with timber of this species (Dadswell 1972; Hillis 1978; INTA 1995; Piter et al. 2004a) and indicate that annual rings and slope of grain can be disregarded for this study. No prohibited defects were observed and, apart from knots, no other defects exceeding the limits established by the American standard were found. 
Table 1. Main results for circumference and length

\begin{tabular}{|c|c|c|c|c|c|c|c|c|}
\hline & \multicolumn{4}{|c|}{ Sample $1(n=57)$} & \multicolumn{4}{|c|}{ Sample $2(n=48)$} \\
\hline & \multicolumn{3}{|c|}{ Circumference at } & \multirow{2}{*}{ Length } & \multicolumn{3}{|c|}{ Circumference at } & \multirow{2}{*}{ Length } \\
\hline & butt & ound 1 & tip & & butt & und & tip & \\
\hline $\operatorname{Min}(\mathrm{mm})$ & 710 & 650 & 465 & 11880 & 625 & 575 & 450 & 7950 \\
\hline Mean $(\mathrm{mm})$ & 893 & 823 & 600 & 11975 & 666 & 627 & 510 & 8010 \\
\hline $\operatorname{Max}(\mathrm{mm})$ & 1100 & 1040 & 775 & 12090 & 735 & 730 & 625 & 8110 \\
\hline $\operatorname{COV}(\%)$ & 9 & 10 & 13 & 0.4 & 4 & 5 & 6 & 0.4 \\
\hline
\end{tabular}

$\mathrm{n}$ : number of poles

The main results for knot dimensions and knot ratio are presented in Table 2. Maximum sizes permitted by the American standard for any single knot in poles less than $13.7 \mathrm{~m}$ long are related to both the pole class and the location of the knot. For classes H6 to 3 the limits are $80 \mathrm{~mm}$ and $130 \mathrm{~mm}$ for the lower and the upper half of length respectively. For classes 4 to 10 the corresponding limits are $50 \mathrm{~mm}$ and $100 \mathrm{~mm}$. Results presented in Table 2 show that no value of $\mathrm{K}$ was greater than the limits adopted by the standard for the upper half of length whereas both limits established for the lower half were exceeded by the maximum value of K obtained for Sample 1 and the limit of $50 \mathrm{~mm}$ was exceeded by the maximum value measured for Sample 2. Nevertheless, a detailed analysis showed that only 3 poles of Sample $1(5 \%)$ and 1 pole of Sample $2(2 \%)$ exceeded the limit of $50 \mathrm{~mm}$ whereas only 1 pole of Sample $1(2 \%)$ exceeded the limit of $80 \mathrm{~mm}$.

Table 2. Main results for knot dimensions and knot ratio

\begin{tabular}{|c|c|c|c|c|c|c|}
\hline & \multicolumn{3}{|c|}{ Sample $1(n=57)$} & \multicolumn{3}{|c|}{ Sample $2(n=48)$} \\
\hline & $\mathrm{K}$ & \multirow{2}{*}{\multicolumn{2}{|c|}{ SuK SuKR }} & \multirow{2}{*}{\multicolumn{2}{|c|}{ SuK }} & \multirow{2}{*}{ SuKR } \\
\hline & L U & & & & & \\
\hline $\operatorname{Min}(\mathrm{mm})$ & 0 & 0 & 0 & $0 \quad 15$ & 18 & 0.03 \\
\hline Mean (mm) & $40 \quad 58$ & 124 & 0.18 & 2634 & 98 & 0.18 \\
\hline $\operatorname{Max}(\mathrm{mm})$ & 100100 & 255 & 0.41 & 6055 & 207 & 0.38 \\
\hline $\operatorname{COV}(\%)$ & 6240 & 52 & 54 & 4627 & 48 & 47 \\
\hline
\end{tabular}

$\mathrm{n}$ : number of poles; K: largest single knot; SuK: largest sum of knots in any $0.31 \mathrm{~m}$;

SuKR: knot ratio; L: lower half of pole length; U: upper half of pole length 
This standard also establishes limits for knot ratio and sum of knots which apply to all pole classes and knot locations. A limit of 0.33 is established for knot ratio expressed as the relation of the greatest sum of knot in any $0.31 \mathrm{~m}$ of the length of the pole and the corresponding average circumference. In addition, the greatest sum of knot in any $0.31 \mathrm{~m}$ of the length of the pole shall not exceed $0.31 \mathrm{~m}$ in any case. The latter limit was easily fulfilled in this case since the maximum value of SuK reached 255 $\mathrm{mm}$ for Sample 1 and $207 \mathrm{~mm}$ for Sample 2. The former limit was slightly exceeded by the maximum values. Nevertheless, a detailed analysis showed that only 3 poles of Sample $1(5 \%)$ and 2 poles of Sample $2(4 \%)$ exceeded the limit of 0.33 established for knot ratio in the American standard mentioned above.

The high COV values presented in Table 2 indicate an important spread of results for these variables. No data related to these growth characteristics were previously published for poles of this species but results corresponding to knot ratio measured on 349 pieces of sawn timber of the same species were reported by Piter et al. (2004a). The published results, which may be used as reference values for this case, range from 0.54 to 0.75 for knot ratio expressed according to four different criteria and they also confirm a very high spread of results for this variable in sawn timber of Argentinean Eucalyptus grandis.

The main results for mechanical properties are summarised in Table 3 where it is possible to appreciate that mean values were greater for Sample 1 than for Sample 2. F and E presented exactly the same COV for both samples whereas F b showed a COV slightly lower for Sample 1 than for Sample 2. A statistical analysis to compare the F mean values of Sample $1\left(62.9 \mathrm{~N} / \mathrm{mm}^{2}\right)$ and Sample $2\left(56.3 \mathrm{~N} / \mathrm{mm}^{2}\right)$ showed that the difference between them is highly significant with an associated probability lower than 0.0005 and similar results were obtained when comparing $\mathrm{F}_{\mathrm{b}}$ and $\mathrm{E}$ mean values corresponding to both samples. It is important to observe that poles of Sample 1 and Sample 2 were randomly selected from the sub-populations of the so-called long and standard poles of Argentinean Eucalyptus grandis (INTA 1995), respectively, which presented different sizes and age. All specimens were then tested according to the same reference conditions. Consequently, the significant difference found between strength and stiffness values corresponding to both sub-populations may be explained by the influence of both pole sizes and age on the analysed properties.

If the difference between mechanical properties results corresponding to the both sub-populations mentioned before is ignored and the 105 poles are analysed as a whole sample, mean values of $\mathrm{F}, \mathrm{F} \mathrm{b}$ and $E$ reach $59.9 \mathrm{~N} / \mathrm{mm}^{2}, 57.9 \mathrm{~N} / \mathrm{mm}^{2}$ and $10300 \mathrm{~N} / \mathrm{mm}^{2}$, respectively. The corresponding COV values are $14 \%, 15 \%$ and $16 \%$ and the lower 5 th percentile reaches $46.1 \mathrm{~N} / \mathrm{mm}^{2}$ and $43.4 \mathrm{~N} / \mathrm{mm}^{2}$ for $\mathrm{F}$ and $\mathrm{F}_{\mathrm{b}}$, respectively. However, considering that for purposes connected with single-pole utility structures these poles are commonly separated in the two groups mentioned above, technical and economical reasons account for the convenience of using the results of Sample 1 for the design of long poles and those of Sample 2 for the design of standard poles. On the one hand, the relatively low spread of results within each sample in comparison with that corresponding to all specimens is important for achieving a uniform level of reliability and minimizing the probability of failure, which is the main purpose of structural design. On the other hand, the relatively high strength and stiffness values found for the long poles (Sample 1) in comparison with those corresponding to all poles can not be utilised unless the poles are separated in the two groups mentioned above. 
Table 3. Main results for maximum fibre stress and modulus of elasticity

\begin{tabular}{cccc|ccc}
\hline & \multicolumn{4}{c|}{ Sample 1 $(\mathrm{n}=57)$} & \multicolumn{3}{|l}{ Sample 2 $(\mathrm{n}=48)$} \\
& & & & & & \\
& $\mathrm{F}$ & $\mathrm{F}_{\mathrm{b}}$ & $\mathrm{E}$ & $\mathrm{F}$ & $\mathrm{F}_{\mathrm{b}}$ & $\mathrm{E}$ \\
\hline Min $\left(\mathrm{N} / \mathrm{mm}^{2}\right)$ & 36.8 & 36.8 & 7383 & 33.8 & 30.9 & 6854 \\
\hline Mean $\left(\mathrm{N} / \mathrm{mm}^{2}\right)$ & 62.9 & 61.8 & 10935 & 56.3 & 53.4 & 9546 \\
\hline Max $\left(\mathrm{N} / \mathrm{mm}^{2}\right)$ & 77.7 & 77.5 & 13883 & 70.2 & 66.8 & 13010 \\
\hline COV $(\%)$ & 13 & 13 & 14 & 13 & 15 & 14 \\
\hline $5^{\text {th }}$ percentile $\left(\mathrm{N} / \mathrm{mm}^{2}\right)$ & 49.9 & 48.8 & - & 43.9 & 40.6 & - \\
\hline
\end{tabular}

$\mathrm{n}$ : number of poles; F: maximum fibre stress at ground line;

$\mathrm{F}_{\mathrm{b}}$ : maximum fibre stress at breaking point; E: modulus of elasticity

Table 3 also shows that the results of maximum fibre stress at ground line were only slightly higher than those at breaking point for Sample 1 . The mean and the $5^{\text {th }}$ percentile values of $F$ were $2 \%$ higher than those corresponding to $\mathrm{F}_{\mathrm{b}}$. A detailed analysis showed that 31 poles of this sample (54\%) broke above the ground line whereas the failure location was coincident with the ground line for the other 26 poles $(46 \%)$. The average distance from break to ground line reached $0.44 \mathrm{~m}$ for the 57 poles of this sample.

Results corresponding to Sample 2 show that the mean and the $5^{\text {th }}$ percentile values of $\mathrm{F}$ were $5 \%$ and $8 \%$ higher, respectively, than those corresponding to $\mathrm{F}_{\mathrm{b}}$. In this case the detailed analysis exhibited that 42 poles $(87 \%)$ broke above the ground line whereas the failure location was coincident with the ground line for the other 6 poles $(13 \%)$. Even though $87 \%$ of the poles broke above ground line in this sample, the average distance from break to ground line reached $0.47 \mathrm{~m}$ which is only slightly higher than that found for Sample 1. Since poles of Sample 2 presented lower taper than those of Sample 1, as it was expressed before, a large taper (Wolfe and Kluge 2005) could not have caused the relatively high number of failures above ground line (87\%) found in Sample 2. Nevertheless, the similarity found between $\mathrm{F}$ and $\mathrm{F}_{\mathrm{b}}$ accounts for the convenience of considering the strength at ground line for calculating the load-carrying capability of this material for practical purposes, in line with the criterion adopted by the American standard ANSI 05.1 (2002).

Even though the poles were tested in unseasoned condition, the mean values of $\mathrm{F}$ are higher than those found by Piter et al. (2004a) for strength of seasoned sawn timber of the same species tested in bending according to the European standard EN 408 (1996). This paper reports mean values ranging from $40.3 \mathrm{~N} / \mathrm{mm}^{2}$ to $53.6 \mathrm{~N} / \mathrm{mm}^{2}$ for bending strength obtained on four samples of beams with different structural sizes. The fact that poles were tested in natural form and longitudinal fibres were not cut as in sawn timber may explain the difference found between strength values corresponding to green poles and seasoned sawn timber of the same species (Winter 1995). The American standard ANSI 05.1c (2004) publishes ground line strength mean values for new, green, untreated poles less than $15.2 \mathrm{~m}$ long of 13 species which are provided for use with reliability-based design procedures. These data were obtained from cantilever bending tests carried out on full-size pole samples and assuming established values for pole circumference and linear pole taper rather than actual pole dimensions. The published strength mean values, which were calculated with modulus of rupture results, range from $28.3 \mathrm{~N} / \mathrm{mm}^{2}$ 
to $70.3 \mathrm{~N} / \mathrm{mm}^{2}$ with $\mathrm{COV}$ values ranging from $12 \%$ to $21 \%$. The mean values obtained in this research for the maximum fibre stress at ground line $\left(62.9 \mathrm{~N} / \mathrm{mm}^{2}\right.$ and $\left.56.3 \mathrm{~N} / \mathrm{mm}^{2}\right)$ compare well with those published by the standard. COV values presented in Table 3 give evidence of a relatively low dispersion of the strength data obtained in this research in comparison with those published by the standard. Since the characteristic strength is based on the $5^{\text {th }}$ percentile value, which is presented in Table 3 , this relatively low spread of data represents a clear advantage of this material for structural purposes.

Modulus of elasticity exhibited a similar COV to that found for strength (Table 3). Contrarily to strength, this mechanical property did not show higher values than those published in the paper mentioned above (Piter et al. 2004a). The mean values reported in this paper for the four samples mentioned before range between $10900 \mathrm{~N} / \mathrm{mm}^{2}$ and $12700 \mathrm{~N} / \mathrm{mm}^{2}$. The American standard ANSI 05.1c (2004) also publishes modulus of elasticity values for new, green, untreated poles less than $15.2 \mathrm{~m}$ long of 13 species. The published mean values range from $9930 \mathrm{~N} / \mathrm{mm}^{2}$ to $23100 \mathrm{~N} / \mathrm{mm}^{2}$ with COV values ranging from $19 \%$ to $25 \%$. The mean values found in this research for modulus of elasticity (10935 N/ $\mathrm{mm}^{2}$ and $9546 \mathrm{~N} / \mathrm{mm}^{2}$ ) are similar to the lower mean value adopted by the standard but this property exhibited lower COV values in the present study (14\%) than those adopted by the standard.

A statistical analysis with the results of both samples showed a very poor correlation between knot ratio, expressed according to SuKR, and strength. The relationship between SuKR and F is presented in figures 2 and 3 for Sample 1 and 2 respectively. An insignificant correlation coefficient of 0.09 was found between these variables for Sample 1 whereas the corresponding value for Sample 2 reached 0.02. These values show that knot ratio, expressed according to SuKR, may not be considered for explaining the strength variability and similar results were found for the correlation between knot ratio and modulus of elasticity.

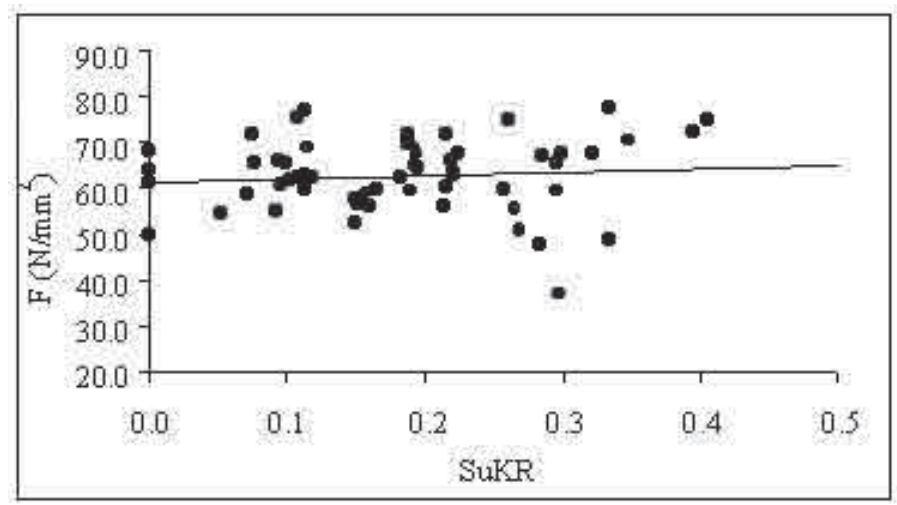

Figure 2. Relationship between SuKR and F for Sample 1

F: maximum fibre stress at ground line; SuKR: relation of the greatest sum of knot in any $0.31 \mathrm{~m}$ of the length of the pole and the average circumference of the same $0.31 \mathrm{~m}$ section; correlation coefficient: 0.09; linear regression equation: $\mathrm{F}=6.9912 \mathrm{SuKR}+61.658$ 


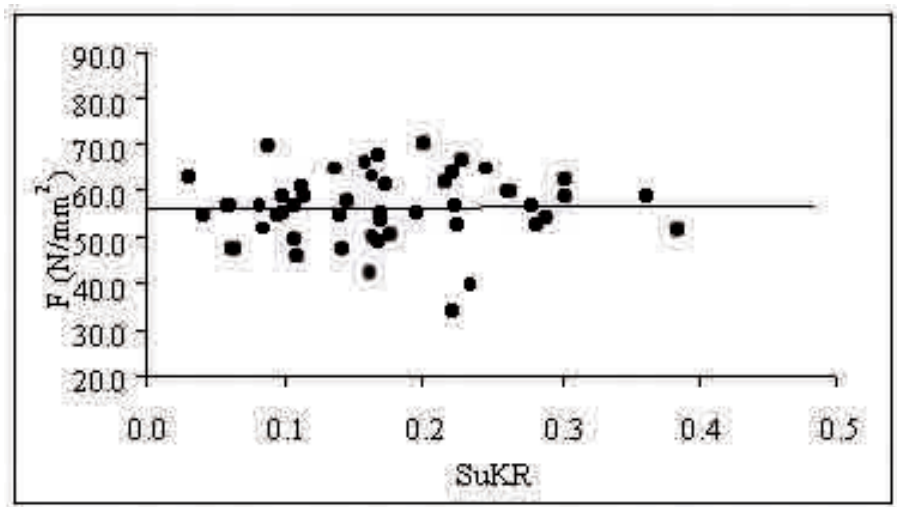

Figure 3. Relationship between SuKR and F for Sample 2

F: maximum fibre stress at ground line; SuKR: relation of the greatest sum of knot in any $0.31 \mathrm{~m}$ of the length of the pole and the average circumference of the same $0.31 \mathrm{~m}$ section; correlation coefficient: 0.02; linear regression equation: $\mathrm{F}=1.9917 \mathrm{SuKR}+55.943$

Wang and Bodig (1991) report a poor effect of maximum single knot on pole strength. According to this paper, the maximum sum of knots in any $0.31 \mathrm{~m}$ interval plays a more significant role in controlling pole strength but this role depends on distance and size of neighbouring knots because these two variables define the superposition of stresses around knots. A detailed analysis showed that only 3 poles of Sample $1(5 \%)$ and 4 poles of Sample $2(8 \%)$ presented knots separated $100 \mathrm{~mm}$ or less. The analysis also showed that these neighbouring knots in any case were greater than $50 \mathrm{~mm}$. A comparison of these results with data published in the paper mentioned above confirms that knot interaction and the consequent superposition of stresses may be disregarded in this case. The results of this detailed analysis are congruent with the insignificant correlation found between SuKR and F (figures 2 and 3). A relatively modest relationship between knot ratio and bending strength was obtained for seasoned sawn timber of Argentinean Eucalyptus grandis in the research mentioned above (Piter et al. 2004a) which reports correlation coefficients ranging from -0.3 to -0.33 for knot ratio expressed according to four different criteria.

Even though knot ratio is considered a visual feature for strength grading this material and limits for knot sizes are established in the standard ANSI 05.1 (2002), the negligible correlation between mechanical properties and knot ratio obtained in this research suggests that the adoption of stringent quality requirements for poles of this species is not convenient where knots are concerned and that this growth characteristic may be disregarded as a visual parameter for strength grading these poles.

Figure 4 displays the relationship between $\mathrm{E}$ and $\mathrm{F}$ for Sample 1. Since the correlation coefficient reached 0.52 , E explains approximately $27 \%$ of the variability of $\mathrm{F}$. The relation found for these 57 green poles is lower than that reported by Piter et al. (2004b) for seasoned sawn timber of the same species. This paper informs a correlation coefficient of 0.81 between bending strength and global modulus of elasticity for 255 structural-sized specimens subjected to bending according to the European standard EN 408 (1996). 


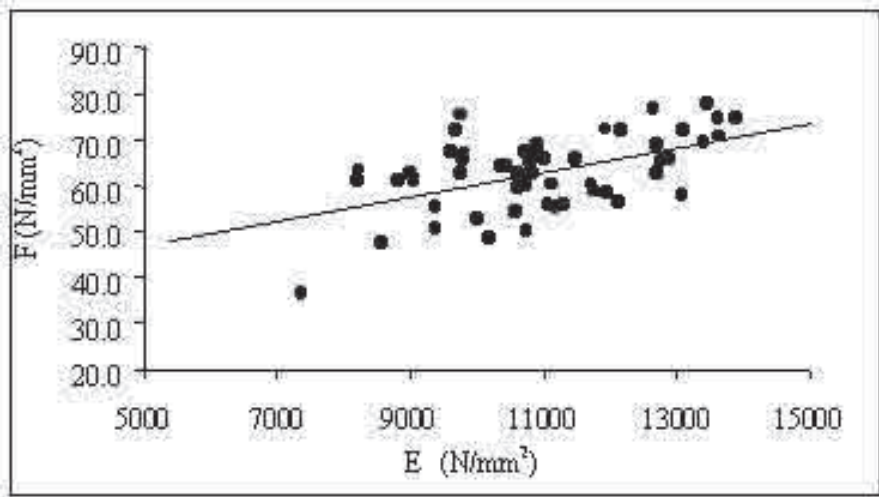

Figure 4. Relationship between E and F for Sample 1

F: maximum fibre stress at ground line; E: modulus of elasticity; correlation coefficient: 0.52 ; linear regression equation: $\mathrm{F}=0.0027 \mathrm{E}+33.918$

The relationship between $\mathrm{E}$ and $\mathrm{F}$ corresponding to the 48 green poles of Sample 2 is displayed in Figure 5, where it is possible to appreciate a lower correlation between both variables than that found for Sample 1. Since the correlation coefficient reached 0.37, E explains approximately $14 \%$ of the variability of $\mathrm{F}$ in this case.

Even though only a modest correlation between E and F was found for Sample 2, the results obtained for Sample 1 and the very good correlation between strength and stiffness reported for seasoned sawn timber of this species (Piter et al. 2004b) encourage further studies aimed at exploring the relationship between $\mathrm{E}$ and $\mathrm{F}$ on the base of a larger number of test than those made in this research. The knowledge of this relationship is also important for studying the possibility of strength grading this material by employing non-destructive methods for determining the modulus of elasticity (Glos 1995; Görlacher 1984).

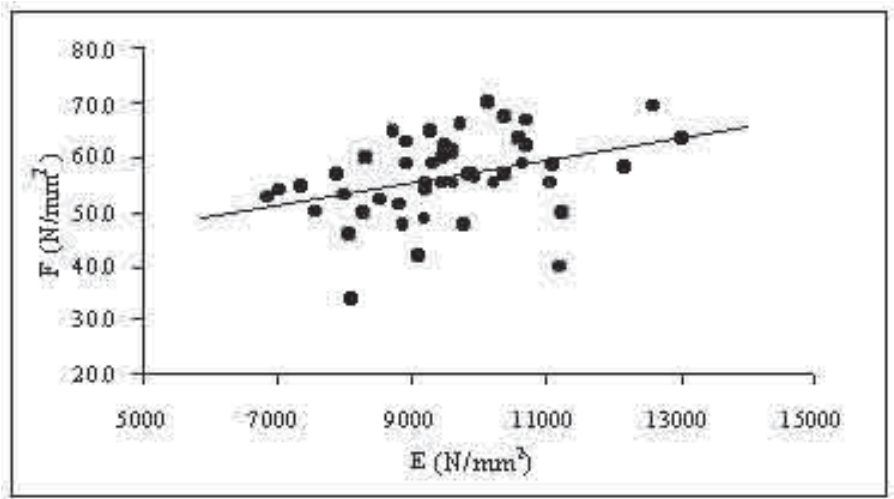

Figure 5. Relationship between E and F for Sample 2

F: maximum fibre stress at ground line; E: modulus of elasticity; correlation coefficient: 0.37 ; linear regression equation: $\mathrm{F}=0.0021 \mathrm{E}+36.659$ 


\section{CONCLUSIONS}

Two test samples containing new, green, untreated poles of Argentinean Eucalyptus grandis with nominal lengths of $12 \mathrm{~m}$ and $8 \mathrm{~m}$, respectively, were tested in bending according to the procedures established in the American standard ASTM D 1036 (2005) and the Argentinean standard IRAM 9529 (2004) for the cantilever test method. Values obtained for the average circumference taper per $0.31 \mathrm{~m}$ of length were similar to those adopted by the American standard ANSI 05.1 (2002) and results found for knot size and knot ratio compare well with those permitted by this American standard. Mean values of both maximum fibre stress and modulus of elasticity were higher for the poles with nominal length of $12 \mathrm{~m}$ than for those of $8 \mathrm{~m}$. A statistical analysis showed a significant difference between mechanical property results corresponding to both groups of poles which differed in sizes and age. Results also showed the convenience of using the values corresponding to each group for achieving a more reliable and economical structural design of utility poles. The similarity found between maximum fibre stress at ground line and at breaking point accounts for the convenience of considering the strength at ground line for calculating the load-carrying capability of this material for practical purposes. Mean values of maximum fibre stress at ground line were greater than strength values reported for seasoned sawn timber of the same species and they compare well with those published by ANSI 05.1c (2004) for poles of different species but the relatively low spread of strength results found in this research in comparison with that adopted by this standard represents a clear advantage of the tested material for structural purposes. Contrarily to strength, mean values found for modulus of elasticity were similar to the lower mean values reported for seasoned sawn timber of the same species and also similar to the lower mean values adopted by the American standard. A negligible relationship between knot ratio and mechanical properties was found. Consequently, the adoption of stringent quality requirements related to knots does not appear to be convenient for these poles and knot ratio may be disregarded as a visual parameter for strength grading this material. The correlation found between modulus of elasticity and strength in both samples encourages further studies regarding the analysis of the relationship between both mechanical properties on a larger statistical base than that adopted in this research. 


\section{REFERENCES}

Alves Dias, A.; Calil Júnior, C.; Soares Miná, A.J. 2004. Avaliação da rigidez e da resistencia de postes de madeira para uso como estacas para fundaçõoes. IX Encontro Brasileiro em Madeiras e em Estruturas de Madeira. Cuiaba, Brasil.

ANSI 05.1. 2002. American National Standard for Wood Poles - Specifications and Dimensions. Alliance for Telecommunications Industry Solutions, Washington DC.

ANSI 05.1c. 2004. American National Standard for Wood Poles and Products - Supplement to ANSI 05.1-2002 (and Consolidation of ANSI 05.1a-2003 and ANSI 05.1b-2003). Alliance for Telecommunications Industry Solutions, Washington DC.

ASTM D 1036. 2005. Standard Test Methods of Static Tests of Wood Poles. American Society for Testing and Materials, West Conshohocken, PA.

Coronel, E.O. 1994. Fundamentos de las propiedades físicas y mecánicas de las maderas. Aspectos teóricos y prácticos para la determinación de las propiedades, y sus aplicaciones. Instituto de Tecnología de la Madera. Serie de publicaciones 9.404. Editorial El Liberal, Santiago del Estero, Argentina.

Dadswell, H. 1972. The Anatomy of Eucalypt Woods. CSIRO Div. Appl. Chem. Tech. Pap. No. 66, Australia.

EN 408. 1996. Holzbauwerke, Bauholz für tragende Zwecke und Brettschichtholz, Bestimmung einiger physikalischer und mechanischer Eigenschaften. Europäisches Komitee für Normung, Beuth Verlag, Berlin.

Glos, P. 1995. Strength grading. In: Timber Engineering STEP 1, Centrum Hout, The Netherlands, pp. A6/1-A6/8.

Görlacher, R. 1984. Ein neues Messverfahren zur Bestimmung des Elastizitätsmoduls von Holz. Holz als Roh- und Werkstoff 42:219-222.

Hillis, W. E. 1978. Wood quality and utilization. In: Eucalypts for Wood Production, eds. W. E. Hillis and A. G. Brown, CSIRO, Melbourne, pp. 258-289.

Hoffmeyer, P. 1995. Wood as a building material. In: Timber Engineering STEP 1, Basis of design, material properties, structural components and joints. Centrum Hout, The Netherlands, pp. A4/1 A4/21.

INTA. 1995. Manual para Productores de Eucaliptos de la Mesopotamia Argentina. Grupo Forestal, Instituto Nacional de Tecnología Agropecuaria EEA Concordia, Argentina.

IRAM 9529. 2004. Maderas, determinación de la resistencia a la flexión de postes de madera. Instituto Argentino de Normalización y Certificación, Buenos Aires.

ISO 3130. 1975. Wood - Determination of moisture content for physical and mechanical tests. International Organization for Standardization.

ISO 3131. 1975. Wood - Determination of density for physical and mechanical tests. International Organization for Standardization. 
Piter, J. C.; Zerbino, R. L.; Blaß, H. J. 2004a. Visual strength grading of Argentinean Eucalyptus grandis. Strength, stiffness and density profiles and corresponding limits for the main grading parameters. Holz als Roh- und Werkstoff 62: 1-8.

Piter, J. C.; Zerbino, R. L.; Bla $\beta$, H. J. 2004b. Machine strength grading of Argentinean Eucalyptus grandis. Main grading parameters and analysis of strength profiles according to European standards. Holz als Roh- und Werkstoff 62: 9-15.

Wang, Y.; Bodig, J. 1991. Knot interaction in wood poles. Wood Science and Technology 25: 4756.

Winter, S. 1995. Roundwood structures. In: Timber Engineering STEP 2, Design-Details and structural systems, Centrum Hout, The Netherlands, pp. E19/1 - E19/10.

Wolfe, R.W.; Bodig, J.; Lebow, P.K. 2001. Derivation of nominal strength for wood utility poles. Gen. Tech. Rep. FPL-GTR-128 (rev.). Madison, WI: U.S. Department of Agriculture, Forest Service, Forest Products Laboratory. $11 \mathrm{p}$.

Wolfe, R.W.; Kluge, R.O. 2005. Designated Fiber Stress for Wood Poles. Gen. Tech. Rep. FPLGTR-158. Madison, WI: U.S. Department of Agriculture, Forest Service, Forest Products Laboratory. $39 \mathrm{p}$. 